\title{
Response of macroinvertebrate communities to thermal regime in small Mediterranean streams (southern South America): Implications of global warming
}

\author{
Pablo Pedreros $^{\mathrm{a}, *}$, Meyer Guevara-Mora ${ }^{\mathrm{b}}$, Alejandra Stehr ${ }^{\mathrm{a}}$, Alberto Araneda ${ }^{\mathrm{a}}$, Roberto Urrutia ${ }^{\mathrm{a}}$ \\ ${ }^{a}$ Faculty of Environmental Sciences \& EULA-Center, University of Concepción, Barrio Universitario $s / n$, Concepción, Chile \\ ${ }^{\mathrm{b}}$ Entomology Laboratory, School Biological Sciences, Universidad Nacional, Heredia, Costa Rica
}

\section{A R T I C L E I N F O}

\section{Keywords:}

Andean stream

Benthic macroinvertebrates

Biodiversity

Stream temperature

Thermal requirements

\begin{abstract}
A B S T R A C T
The seasonal nature of the stream thermal regime has been recognized as an important factor for the structure of benthic macroinvertebrate communities. In this study, we show the importance of temperature and the potential implications of global warming on the composition of benthic macroinvertebrate communities in Andean watersheds. Here we show that thermal factors (mean temperature and monthly range) partially explain the seasonal variability of macroinvertebrates in Andean streams. Different thermal requirements were observed for macroinvertebrate families. Optimal monthly mean temperatures estimated for Gripopterygidae (Plecoptera), Hydrobiidae (Gastropoda) and Helicophidae (Trichoptera) were lower than $7{ }^{\circ} \mathrm{C}$, while temperatures for Ameletopsidae, Baetidae (Ephemeroptera), Ecnomidae, Limnephilidae, Hydropsychidae, Leptoceridae (Trichoptera), Elmidae (Coleoptera) and Notonemouridae (Plecoptera) were close to $9.5^{\circ} \mathrm{C}$.

According to our estimations, future global warming could cause important changes in the macroinvertebrate composition of Andean watersheds. Gripopterygidae, Austroperlidae, Diamphipnoidae (Plecoptera), Hydrobiidae and Helicophidae (Trichoptera) would be the most vulnerable families under the 2090 temperature predictions due to their preference for low temperature.
\end{abstract}

\section{Introduction}

Temperature is crucial in the life cycle of aquatic ectotherms (Angilletta et al., 2002; Caissie, 2006), since it influences their metabolic growth rate and feeding (Eriksen, 1964; Vannote and Sweeney, 1980; Kishi et al., 2005), fecundity (Brittain, 1991) and emergence patterns (Watanabe et al., 1999; McKie et al., 2004). However, studies in recent years indicate that the progressive temperature increase on the Earth's surface due to global warming is gradually modifying the thermal regime of rivers and streams (Kaushal et al., 2010; Van Vliet et al., 2011; Isaak et al., 2012). The alteration in the water temperature could have a negative impact on the community structure of aquatic invertebrates (Heino et al., 2009; Hering et al., 2009), since thermally sensitive organisms could be forced to change their range of geographical distribution (Parmesan and Yohe, 2003; Chessman, 2009, 2012). Indeed, a better understanding of the thermal sensitivity or tolerance of species could be fundamental to predicting and/or projecting the vulnerability of biota to global warming in various climate regions.
Global circulation models indicate that the Earth's surface temperature has increased by $0.78^{\circ} \mathrm{C}$ between $1850-2012$ period and project an average increase of over $3.7^{\circ} \mathrm{C}$ by the end of the century (IPCC, 2013). In South America, impacts associated with these climate trends are evident and consistent with the physical effects reported in North America and Europe (Rosenzweig et al., 2008). In central Chile, studies carried out in the last decade have demonstrated that the height of the $0{ }^{\circ} \mathrm{C}$ isotherm has shifted (Carrasco et al., 2005) and the air temperature has increased by approximately $0.25^{\circ} \mathrm{C} /$ decade in the Andes zone (Falvey and Garreaud, 2009). In addition, it is projected that the average air temperature of this area could increase by between 2 and $4{ }^{\circ} \mathrm{C}$ by 2100 (CONAMA, 2006). Nonetheless, the impact of these new temperature regimes have uncertain effects on the functional processes of freshwater Andean ecosystems.

The effects of global warming on freshwater species in rivers has been well reported in North America (Poff et al., 2010), Europe (Durance and Ormerod, 2007; Haidekker and Hering, 2008; Hering et al., 2009; Domisch et al., 2013), Oceania (Chessman, 2009, 2012; Mantyka-Pringle et al., 2014) and Asia (Li et al., 2012, 2013). However,

\footnotetext{
* Corresponding author.

E-mail addresses: papedrer@udec.cl, papedrer@gmail.com (P. Pedreros).
} 
the response is not well understood in South America, even though these areas have a high level of endemism and taxonomic richness (Myers et al., 2000; Filipe et al., 2013). According to Bêche and Resh (2007b), the sensitivity of organisms to environmental conditions will determine their abundance and geographical distribution. Ward and Stanford (1982) suggested that temperature is fundamental to the distribution of benthic macroinvertebrates, since most have specific ranges around an optimum that they can tolerate (Dallas and Rivers-Moore, 2012; Dallas and Ross-Gillespie, 2015). It is probable that the species that inhabit low-order rivers at high altitudes are intolerant to high temperatures, given their limited capacity to face severe environmental changes (Bêche and Resh, 2007a, 2007b; Hering et al., 2009; Filipe et al., 2013).

Particularly in the Mediterranean-climate region of Chile, the impact of global warming on freshwater aquatic communities could be a relevant threat for aquatic conservation due to high endemism, diversity and richness of specific taxonomic groups (Habit et al., 2010; Valdovinos, 2008; Figueroa et al., 2013). Therefore, stenothermic species in the rivers and streams of the Andes area are expected to be more vulnerable with fastest responses to the projected temperature increase (CONAMA, 2006).

This investigation had two objectives: (a) determine the influence of temperature on benthic macroinvertebrate community composition and (b) assess the potential risk global-warming on Andean streams ecosystems using the families of macroinvertebrates.

\section{Materials and methods}

\subsection{Study area}

This study was conducted in three streams of the Biobio watershed, specifically: Lomín ( $38^{\circ} 00^{\prime} 57.24^{\prime \prime} \mathrm{S} ; 71^{\circ} 17^{\prime} 24.02^{\prime \prime}$ W; $936 \mathrm{~m}$ a.s.1.), Quepuca (38 $03^{\prime} 8.05^{\prime \prime}$ S; $71^{\circ} 24^{\prime} 57.22^{\prime \prime}$ W; $750 \mathrm{~m}$ a.s.l.) and Pangue
( $37^{\circ} 53^{\prime} 45.04^{\prime \prime} \mathrm{S} ; 71^{\circ} 36^{\prime} 51.79^{\prime \prime} \mathrm{W} ; 475 \mathrm{~m}$ a.s.1.), which have drainage areas of $214.52 \mathrm{~km}^{2}, 35.32 \mathrm{~km}^{2}$ and $156.03 \mathrm{~km}^{2}$, respectively (Fig. 1). The study area was located in the sub-Andean deciduous forest biome (Gajardo, 1994), where the predominant riparian tree species is Nothophagus spp. (Blume) or Drymis winteri (J. R. et Forster) (Dallman, 1998; Hajek, 1991). The climate in this area is highly seasonal, with cool-wet winters and hot-dry summers (Köppen, 1923). During the study period rainfall varied between 7.0 and $344.5 \mathrm{~mm}$, while the air temperature varied between 1.61 and $15.98^{\circ} \mathrm{C}$. In the streams, the flow regime has two high flow peaks: one associated with the rainy period (May to June) and another with snowmelt (September to November). The upper section of Biobio watershed is relevant for aquatic ecosystem conservation, given the high diversity and endemism of freshwater invertebrates (Valdovinos, 2008; Figueroa et al., 2013) also this area has scarce anthropic intervention, facilitating the opportunity to evaluate the influence of temperature on benthic macroinvertebrates.

\subsection{Characteristics of river habitat and sampling}

In each stream, we selected a 30-m reach with similar pool-riffle morphology and aquatic substrate with a mix of boulders, stones, gravel, sand and leaf packs from the riparian vegetation (e.g., small stems, leaves, and bark). For each study section, physico-chemical, hydrological and thermal variables were measured monthly from July 2010 to May 2011. In-stream physico-chemical parameters included temperature $\left({ }^{\circ} \mathrm{C}\right)$, dissolved oxygen (HI-9146 N DO meter; mg/L), $\mathrm{pH}$ (HI-98172 N pH meter) and conductivity (HI 9835 conductivity meter $\mu \mathrm{S} / \mathrm{cm}$ ). Hydrological variables included river width, measured with a measuring tape graduated in $\mathrm{cm}$, and current velocity, measured with a digital velocity meter (Flow Probe model FP111), close to temperature data logger. Thermal variables were measured every $15 \mathrm{~min}$ for 11 months using $\mathrm{HOBO}$ data loggers (UA-001-08; $-20^{\circ}$ to $70^{\circ} \mathrm{C}$ ) with prior 24 -h calibration. Upon in situ installation, the temperature sensors were

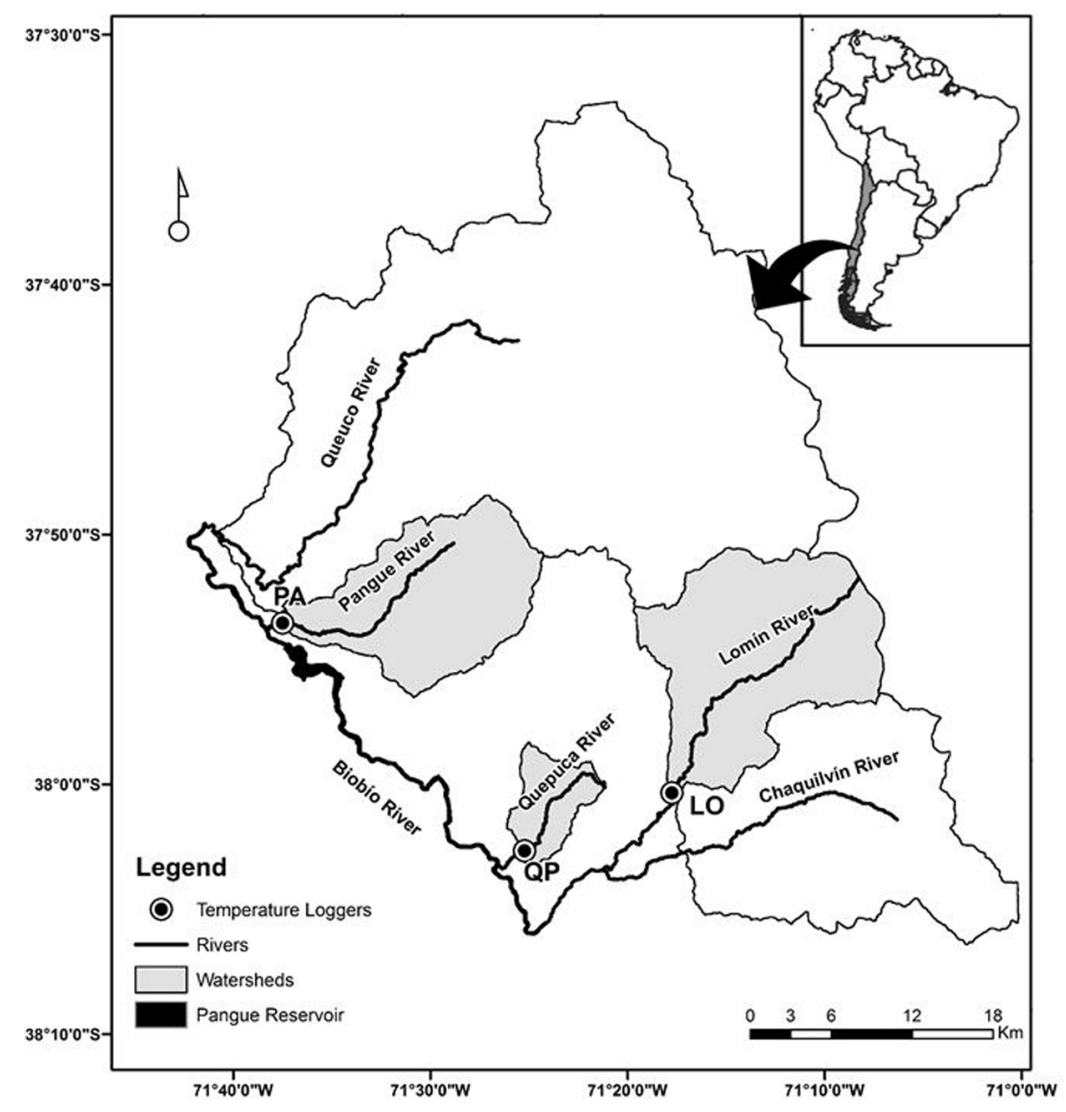

Fig. 1. Location of study sites in the Andean zone of the Biobio River basin. 
Table 1

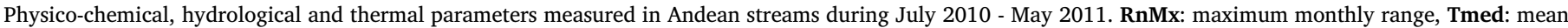

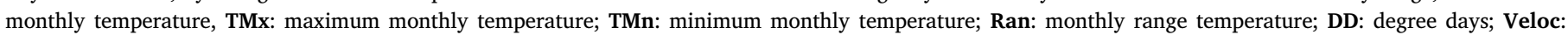
current velocity; Width: river width; Cond: electric conductivity y DO: dissolved oxygen.

\begin{tabular}{|c|c|c|c|c|c|c|c|c|c|c|c|c|}
\hline & \multicolumn{7}{|c|}{ Thermal } & \multicolumn{2}{|c|}{ Hydrological } & \multicolumn{3}{|c|}{ Physico-chemical } \\
\hline & $\begin{array}{l}\text { RnMx } \\
\left({ }^{\circ} \mathrm{C}\right)\end{array}$ & $\begin{array}{l}\text { Tmed } \\
\left({ }^{\circ} \mathrm{C}\right)\end{array}$ & & $\begin{array}{l}\text { TMx } \\
\left({ }^{\circ} \mathrm{C}\right)\end{array}$ & $\begin{array}{l}\text { TMn } \\
\left({ }^{\circ} \mathrm{C}\right)\end{array}$ & $\begin{array}{l}\text { Ran } \\
\left({ }^{\circ} \mathrm{C}\right)\end{array}$ & $\begin{array}{l}\mathrm{DD} \\
\left({ }^{\circ} \mathrm{C}\right)\end{array}$ & $\begin{array}{l}\text { Width } \\
\text { (m) }\end{array}$ & $\begin{array}{l}\text { Veloc } \\
(\mathrm{m} / \mathrm{s})\end{array}$ & $\begin{array}{l}\text { Cond } \\
(\mu \mathrm{S} / \mathrm{cm})\end{array}$ & $\begin{array}{l}\text { DO } \\
(\mathrm{mg} / \mathrm{L})\end{array}$ & $\mathrm{pH}$ \\
\hline Lomín July & 2.68 & 5.01 & 7.58 & & 2.84 & 4.74 & 111.30 & 10.00 & 0.36 & 82.00 & 10.46 & 7.28 \\
\hline Lomín August & 3.82 & 5.37 & 8.68 & & 2.41 & 6.27 & 156.50 & 10.00 & 0.34 & 87.00 & 10.76 & 7.36 \\
\hline Lomín October & 6.56 & 7.23 & 12.11 & & 4.31 & 7.80 & 224.13 & 9.00 & 0.42 & 91.00 & 9.32 & 7.16 \\
\hline Lomín January & 6.70 & 11.91 & 16.90 & & 7.38 & 9.52 & 369.18 & 8.00 & 0.37 & 88.00 & 8.80 & 7.36 \\
\hline Lomín February & 6.53 & 12.16 & 16.05 & & 8.08 & 7.97 & 340.37 & 8.00 & 0.22 & 89.00 & 8.70 & 7.33 \\
\hline Lomín March & 5.42 & 10.77 & 15.76 & & 7.18 & 8.58 & 333.98 & 10.00 & 0.28 & 84.00 & 10.20 & 7.32 \\
\hline Lomín April & 4.69 & 8.55 & 13.01 & & 4.31 & 8.70 & 256.57 & 10.00 & 0.30 & 86.00 & 10.40 & 7.23 \\
\hline Lomín May & 3.31 & 7.08 & 9.97 & & 4.52 & 5.45 & 219.40 & 11.00 & 0.50 & 82.00 & 10.20 & 7.26 \\
\hline Quepuca July & 2.42 & 3.96 & 5.55 & & 1.76 & 3.79 & 83.70 & 6.00 & 0.45 & 55.00 & 10.80 & 7.18 \\
\hline Quepuca September & 3.88 & 5.73 & 8.18 & & 3.58 & 4.60 & 173.05 & 7.00 & 0.65 & 59.00 & 10.44 & 7.27 \\
\hline Quepuca October & 5.73 & 6.49 & 10.94 & & 4.00 & 6.94 & 206.53 & 7.00 & 0.70 & 49.00 & 9.00 & 7.26 \\
\hline Quepuca November & 7.56 & 8.15 & 13.17 & & 4.10 & 9.07 & 243.90 & 7.00 & 0.65 & 53.00 & 9.02 & 7.28 \\
\hline Quepuca December & 8.49 & 10.27 & 17.86 & & 4.31 & 13.55 & 328.64 & 6.00 & 0.50 & 48.00 & 9.00 & 7.12 \\
\hline Quepuca January & 8.30 & 12.69 & 19.28 & & 7.78 & 11.50 & 389.48 & 5.00 & 0.45 & 50.00 & 8.90 & 7.04 \\
\hline Quepuca February & 7.96 & 12.95 & 18.43 & & 7.78 & 10.65 & 364.96 & 4.00 & 0.20 & 50.00 & 8.00 & 7.15 \\
\hline Quepuca March & 7.33 & 10.53 & 17.76 & & 6.06 & 11.70 & 318.42 & 4.00 & 0.25 & 44.00 & 10.70 & 7.07 \\
\hline Quepuca April & 4.38 & 7.47 & 12.40 & & 4.00 & 8.40 & 217.50 & 6.00 & 0.30 & 41.00 & 10.80 & 7.24 \\
\hline Quepuca May & 2.68 & 5.51 & 7.68 & & 2.84 & 4.84 & 168.90 & 6.00 & 0.65 & 38.00 & 11.60 & 7.22 \\
\hline Pangue July & 4.55 & 4.93 & 7.28 & & 2.73 & 4.55 & 103.73 & 12.00 & 0.43 & 50.00 & 10.23 & 7.07 \\
\hline Pangue August & 6.99 & 5.64 & 10.36 & & 3.37 & 6.99 & 174.69 & 12.00 & 0.65 & 56.50 & 11.27 & 7.15 \\
\hline Pangue September & 4.74 & 6.94 & 10.36 & & 4.42 & 5.94 & 208.00 & 13.00 & 0.57 & 56.00 & 10.88 & 7.12 \\
\hline Pangue October & 6.86 & 7.79 & 12.69 & & 4.21 & 8.48 & 241.49 & 13.00 & 0.64 & 50.00 & 11.51 & 7.27 \\
\hline Pangue November & 6.77 & 9.60 & 14.52 & & 5.04 & 9.48 & 285.04 & 13.00 & 0.62 & 54.00 & 10.28 & 7.16 \\
\hline Pangue January & 7.84 & 13.62 & 20.04 & & 8.68 & 11.36 & 422.28 & 9.00 & 0.23 & 45.00 & 7.93 & 7.11 \\
\hline Pangue February & 7.16 & 13.88 & 19.19 & & 8.98 & 10.21 & 388.56 & 8.00 & 0.21 & 44.00 & 8.66 & 7.09 \\
\hline Pangue March & 6.03 & 11.83 & 18.05 & & 7.28 & 10.77 & 366.82 & 9.00 & 0.33 & 42.00 & 9.00 & 7.14 \\
\hline Pangue April & 5.27 & 9.11 & 14.33 & & 5.55 & 8.78 & 273.21 & 10.00 & 0.37 & 46.00 & 9.94 & 7.23 \\
\hline Pangue May & 2.94 & 7.21 & 9.77 & & 4.73 & 5.04 & 223.49 & 12.00 & 0.45 & 37.00 & 12.61 & 7.26 \\
\hline
\end{tabular}

protected from direct radiation in PVC pipes to avoid measurements errors. The monthly thermal parameters considered in the statistical analyses were: mean temperature (Tmed), minimum temperature (TMn), maximum temperature (TMx), monthly range (Ran), maximum monthly range (RnMx) and monthly degree days (DD). Monthly range corresponds to the difference between maximum and minimum temperature and monthly degree days to sum of the temperatures above $0{ }^{\circ} \mathrm{C}$ (Haidekker and Hering, 2008).

Six macroinvertebrate samples were collected monthly from July 2010 to May 2011 (Table 1 ) in each stream using a $0.09 \mathrm{~m}^{2}$ Surber net with 250- $\mu \mathrm{m}$ mesh size (Lomín Stream, $\mathrm{n}=8$ months; Quepuca Stream, $\mathrm{n}=10$ months; Pangue Stream, $\mathrm{n}=10$ months), applying the multihabitat method proposed by Hering et al. (2004). The macroinvertebrates were sorted and identified at family level, following the taxonomic guides of Domínguez et al. (2006); Domínguez and Fernandez (2009) and Stark et al. (2009). We considered only the total and relative abundance of Coleoptera, Ephemeroptera, Gastropoda, Plecoptera and Trichoptera because they are highly vulnerable to global warming (Fochetti and Tierno de Figueroa, 2008; Haidekker and Hering, 2008; Tierno de Figueroa et al., 2010). The thermal tolerance tends to vary within families of freshwater macroinvertebrates and some species tends to be more sensitive to temperature changes, however the scarce information about life cycles and species taxonomic resolution includes a limitation for species thermal resolution, e.g. Gripopterygidae (Plecoptera). Family level identification is an opportunity to improve the easy determination of aquatic ecosystem changes in future climate change scenarios.

\subsection{Statistical analysis}

The biological matrix of the total abundance of macroinvertebrates from all sites was first transformed to $\log (x+1)$ and environmental variables were standardized to mean $=0$, standard deviation $=1$ (Anderson et al., 2006). Detrended Correspondence Analysis (DCA) was used as a preliminary test to determine the gradient length. The length of the first axes for the macroinvertebrate community was $<2 \mathrm{SD}$, indicating that a linear model (rather than a unimodal model) was more appropriate to explain the structure data (Lêps and Ŝmilauer, 2003). Redundancy analysis (RDA) was selected to interpret the relationships between environmental factors (physico-chemical, hydrological and temperature variables) and the macroinvertebrate community. The main environmental variables explaining the variability of the biological data were selected with a forward selection model. The Bonferroni correction was used to avoid the influence of redundant variables, while the significance of each variable was tested using the Monte Carlo Test (999 permutations, $\mathrm{p}<0.05$ ) (Borcard et al., 2011). Pearson correlations between the first two canonical axes and environmental variables were performed to interpret the significance of these axes.

Additionally, partial RDA analyses (pRDA) were run to estimate the relative importance of thermal variables in relation to the physicochemical and hydrological variables (Borcard et al., 2011). The selected variables in the RDA model were treated as explanatory variables and covariates in order to obtain the individual effect of each group of variables. All statistical analyses were performed using $\mathrm{R}$ software 3.1.3; Vegan 2.3-5 package (Oksanen et al., 2016).

Weighted Average Regression Models (WARMs) were used to calculate the optimum and tolerance values (ter Braak and Looman, 1986) of the macroinvertebrate families in relation to temperature descriptors previously selected for the RDA model. The optimum temperature for each taxon was estimated as the average value of the environmental variable, weighted by the relative abundance of this taxon during the months of study. The tolerance was calculated as the weighted standard deviation of the relative abundance of the taxon during the months of study Birks et al. (1990). 
Future air temperature (monthly mean) projections from A2 and B2 climatic scenarios were obtained from the Geophysics Department at the University of Chile (http://www.dgf.uchile.cl/PRECIS/). According to CONAMA (2006), the projection models include an increase of $2-4{ }^{\circ} \mathrm{C}$ (A2: severe scenario) or $<1{ }^{\circ} \mathrm{C}$ (B2: moderate scenario) for the 2071-2100 period. The monthly water temperature was obtained by calculating a linear regression model, based on 43 river time series from 13 countries (Morrill et al., 2005):

Future water temperature $=2.56+0.71$ projected future air temperature (A2 and B2 climatic scenarios)

Finally, the maximum tolerance of macroinvertebrates to average water temperature was calculated as the sum of the optimal values and the previously calculated tolerance values. This calculated value was used as a reference to assess the potential implications of global warming on the aquatic community. If this value is lower than the projected water temperature in the stream, the family can be considered at risk because there is no adequate thermal habitat. For example, by the 2070s, if the maximum tolerance calculated for any Plecoptera family was lower the expected water temperature in Lomin stream $\left(7.74^{\circ} \mathrm{C}\right.$; Table 3$)$, the family would be considered at risk for that decade. The percentage of risk (\% Risk) in future decades (2070, 2080 and 2090) was calculated as the ratio between the number of families at risk (n risk) and the total number of recorded families in all the stream reaches (N total) (Li et al., 2013):

$\%$ Risk $=(\mathrm{n}$ risk $/ \mathrm{N}$ total $) \cdot 100$

\section{Results}

The monthly average temperature of the water fluctuated between 3.96 and $13.88^{\circ} \mathrm{C}$, while minimum and maximum monthly values ranged from 1.76 to $8.98^{\circ} \mathrm{C}$ and $5.50-20.04^{\circ} \mathrm{C}$, respectively (Table 1). Other parameters (e.g., average and maximum monthly range) showed similar differences between the minimum and maximum records, with the highest differences in December and January for all the sampling sites. A decrease in flow velocity (minimum $0.40 \mathrm{~m} / \mathrm{s}$ ) and river width (minimum $10 \mathrm{~m}$ ) was measured during the summer months (January, February and March). The lowest records of pH (7.04-7.36), dissolved oxygen $(7.93-12.61 \mathrm{mg} / \mathrm{L})$ and electrical conductivity $(37-91 \mu \mathrm{S} / \mathrm{cm})$ were determined in the summer months.

In the three studied sites, we collected $\sim 37,000$ individuals from 25 different macroinvertebrate families. The total macroinvertebrate density ranged from 183,122 to 29,748 individuals $/ \mathrm{m}^{2}$ (mean = $22,806.79 \pm 6,098.76)$. Among the 28 samples, the mean family richness ranged from 5 and 18, with a mean value of $14 \pm 3$. The variance explained by the RDA model for the three groups of environmental variables was $47.7 \%(\mathrm{~F}=4.01, \mathrm{p}<0.001)$, with highly significant RDA 1 and 2 axes $(\mathrm{p}<0.001)$. Five environmental variables were selected, all with a variation inflation factor $<5$. The variables selected were current velocity, conductivity, width, monthly range, and mean monthly temperature; explaining $17.7 \%, 12.2 \%, 6.9 \%, 6.2 \%$, and $4.8 \%$ of the total variance, respectively. Based on these five variables, the first axis of the RDA explained $24.1 \%$ of the variability of the macroinvertebrate assemblage and was positively correlated with current velocity. The second axis explained $11.1 \%$ of the assemblage and was positively correlated with mean temperature and monthly range (Table 2). The partial RDAs of the final model indicated that the individual effect of the temperature range and mean monthly temperature accounted for $11.0 \%$ of the variation.

According to the RDA analysis, some benthic macroinvertebrate families such as Austroperlidae or Gripopterygidae were positively correlated with current velocity (Fig. 2). Meanwhile, Elmidae, Hydropsychidae, Hydrobiosidae, Hydroptilidae and Perlidae were positive correlated with mean monthly temperature. Other families like Chilinidae, Philopotamidae, Helicophidae and Psephenidae were highly
Table 2

Statistical summary of the RDA model. Pearson correlation of the canonical axes and selected environmental variables * $\mathrm{p}<0.05$ and $* * \mathrm{p}<0.001$.

\begin{tabular}{lll}
\hline Statistics & Axis 1 & Axis 2 \\
\hline Eigenvalues & 1.24 & 0.57 \\
Cumulative variance (\%) of the species & 0.24 & 0.35 \\
Cumulative variance (\%) of species-related environmental & 0.51 & 0.74 \\
$\quad$ variables & & \\
Correlation with the first two canonical axes & & \\
Current velocity & $0.77^{* *}$ & -0.22 \\
Conductivity & $-0.61^{* *}$ & $-0.47^{*}$ \\
River width & 0.09 & -0.24 \\
Monthly range temperature & -0.30 & $0.44^{*}$ \\
Monthly mean temperature & $-0.51^{* *}$ & $0.56^{* *}$ \\
\hline
\end{tabular}

Table 3

Future projections of mean water temperature $\left({ }^{\circ} \mathrm{C}\right)$ under scenarios A2 and B2 for the 2070s, 2080s and 2090s in Andean streams.

\begin{tabular}{llllllll}
\hline \multirow{2}{*}{ Stream } & \multicolumn{2}{l}{ Scenario A2 } & \multicolumn{5}{l}{ Scenario B2 } \\
\cline { 2 - 3 } \cline { 6 - 7 } \cline { 6 - 8 } & $2070 \mathrm{~s}$ & $2080 \mathrm{~s}$ & $2090 \mathrm{~s}$ & & $2070 \mathrm{~s}$ & $2080 \mathrm{~s}$ & $2090 \mathrm{~s}$ \\
\hline Lomín & 7.74 & 8.53 & 8.67 & & 7.36 & 7.49 & 7.69 \\
Quepuca & 9.01 & 9.72 & 9.85 & & 8.67 & 8.73 & 8.91 \\
Pangue & 9.03 & 9.74 & 9.86 & & 8.68 & 8.75 & 8.92 \\
\hline
\end{tabular}

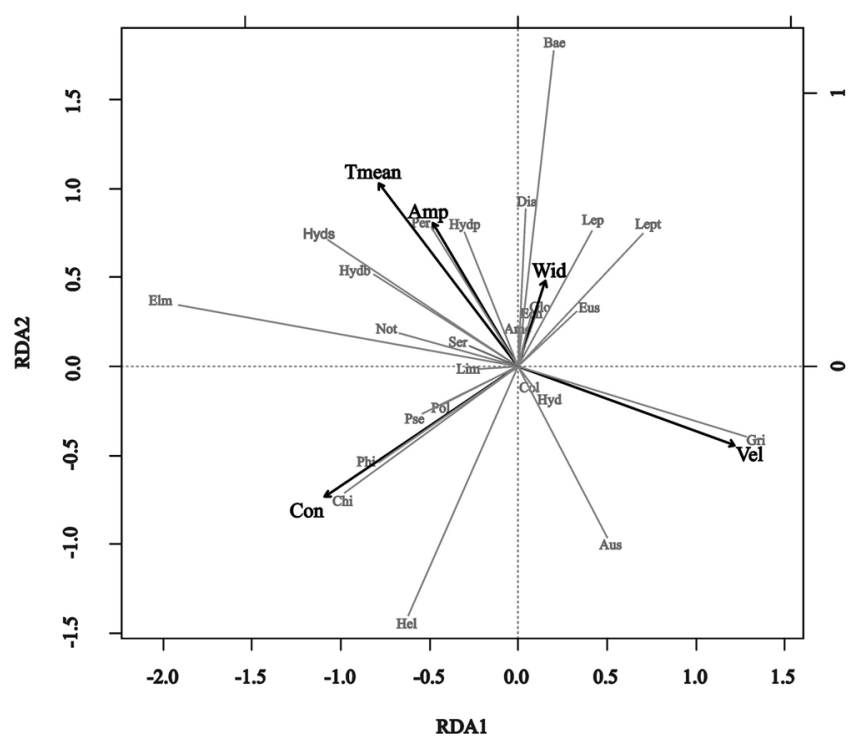

Fig. 2. Tri-plot of the final RDA model for families of macroinvertebrates and environmental variables. Vel: current velocity, Wid: river width, Con: conductivity, Tmed: mean monthly temperature, Ran: monthly range temperature, Ame: Ameletopsidae, Aus: Austroperlidae, Bae: Baetidae, Chi: Chilinidae, Col: Coloburiscidae, Dia: Diamphipnoidae, Ecn: Ecnomidae, Elm: Elmidae, Eus: Eustheniidae, Glo:Glossosomatidae, Gri: Gripopterygidae, Hel: Helicophidae, Hyd: Hydrobiidae, Hydb: Hydrobiosidae, Hyds: Hydropsychidae, Hydp: Hydroptilidae, Lep: Leptophlebiidae, Lept: Leptoceridae, Lim: Limnephilidae, Not: Notonemouridae, Per: Perlidae, Phi: Philopotamidae, Pol: Polycentropodidae, Pse: Psephenidae, Ser: Sericostomatidae.

correlated with the water conductivity parameter.

Optimal values of mean monthly temperature and monthly range for 25 families of macroinvertebrates found in the study area fluctuated between $6.5-11.4{ }^{\circ} \mathrm{C}$ and $6.3-10.3{ }^{\circ} \mathrm{C}$, respectively (Fig. 3). The families Limnephilidae, Notonemouridae, Ameletopsidae, Ecnomidae, Elmidae, Hydropsychidae, Leptoceridae and Baetidae presented optimal values for mean monthly temperature $>9.5^{\circ} \mathrm{C}$, while Hydrobiidae, Gripopterygidae and Helicophidae were restricted to mean temperatures $<7^{\circ} \mathrm{C}$ (Fig. 3a). Among these, Gripopterygidae and Helicophidae 
(a)

Monthly mean temperature $\left({ }^{\circ} \mathrm{C}\right)$

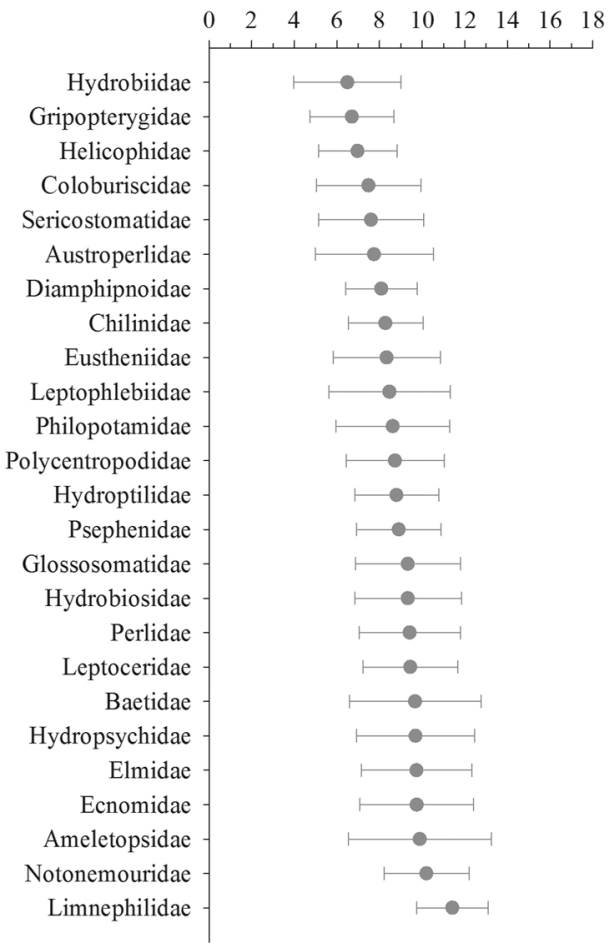

(b)

Monthly range temperature $\left({ }^{\circ} \mathrm{C}\right)$

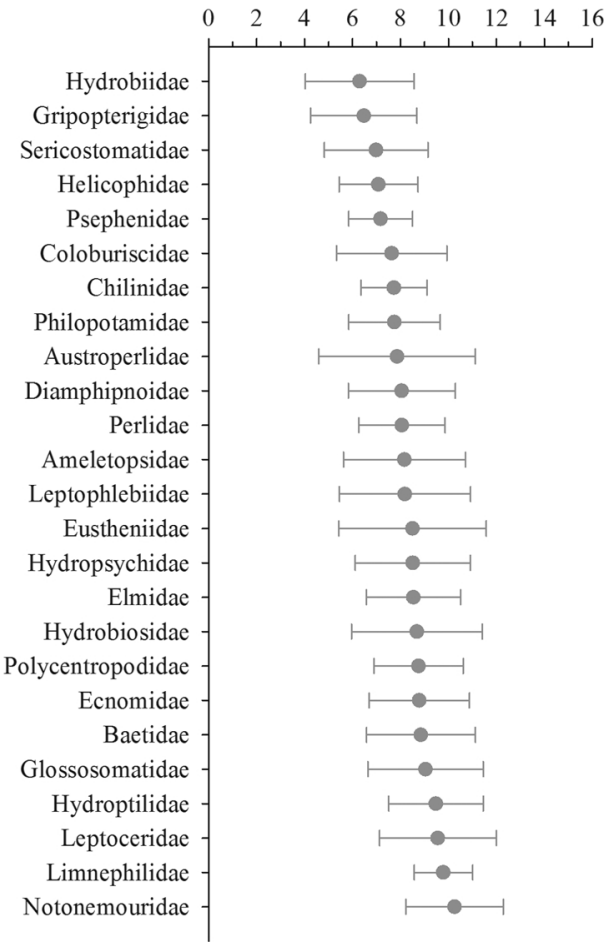

Fig. 3. Optimal value (mode) and tolerance (error bars) for: (a) monthly mean temperature and (b) monthly range temperature for the 25 macroinvertebrate families found in the studied Andean streams. Families are listed on the axis in ascending order of optimal value of each thermal descriptor.

showed narrow water temperature tolerances, indicating that these families are restricted to low temperatures. Regarding the monthly range of Gripopterygidae and Hydrobiidae, they presented optimal values with temperature fluctuations $<6.5^{\circ} \mathrm{C}$, while Notonemouridae, Limnephilidae, Leptoceridae and Hydroptilidae achieved optimal values with fluctuations $>9.5^{\circ} \mathrm{C}$ (Fig. $3 \mathrm{~b}$ ).

According to the future projections of water temperature, the greatest increase in this parameter was projected in the 2090s under the A2 and B2 scenarios (Table 3). Regarding the macroinvertebrate assemblage, important changes were observed at each site under both scenarios (Fig. 4). The groups Plecoptera (Gripopterygidae, Austroperlidae and Diamphipnoidae), Gastropoda (Hydrobiidae) and Trichoptera (Helicophidae) would be the most threatened. Of the three Andean streams studied, Quepuca would experience the greatest loss of

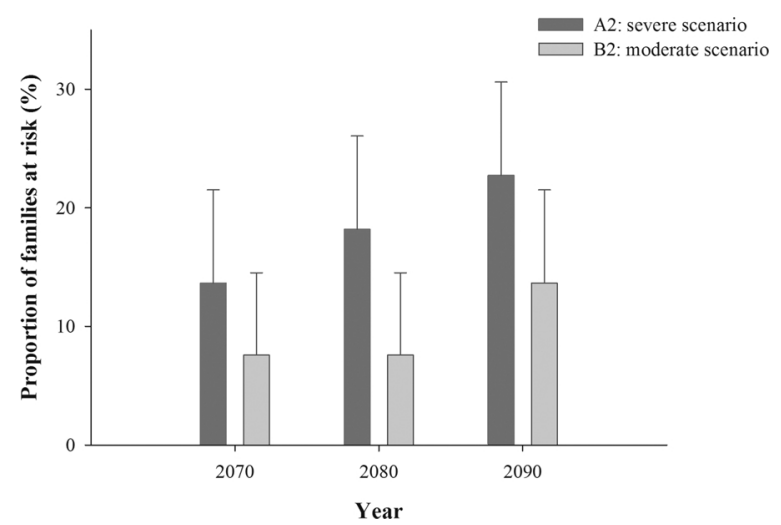

Fig. 4. Proportion of families at risk of disappearance on under emission scenarios A2 (severe) and B2 (moderate) of climate change. The vertical bars represent the mean of three streams and the whiskers represent the standard deviation of the mean. biodiversity under scenarios A2 and B2, losing approximately 7 and 5 families representing $31.8 \%$ and $22.7 \%$, respectively.

\section{Discussion}

Our observations demonstrate that the temperature partially explained the macroinvertebrate community composition in Mediterranean Andean streams. These results were consistent with those obtained by Haidekker and Hering (2008), who found in small rivers of Germany that the temperature explains almost a third of the spatial variability of macroinvertebrates. Others studies also have confirmed that in low-order streams the temperature is a relevant factor in macroinvertebrate community composition because the families, and particularly the species, have different abilities to tolerate water temperature (Hawkins et al., 1997; Brittain et al., 2003; Gustafson, 2008). For example, Sweeney (1993) found that differences in temperature between 2 and $5{ }^{\circ} \mathrm{C}$ cause significant changes in the composition of macroinvertebrates. In this context, our study clearly showed that some families were highly sensitive to the temperature pattern, while others exhibited more eurythermic behavior.

The thermal descriptors that most influence the beetles, mayflies, stoneflies, snails and caddisflies assemblages were mean temperature and monthly range. The other analyzed thermal variables (TMx, TMn, RnMX and DD) were strongly correlated with the descriptors included in the RDA model $(r>0.70 ; p=0.001)$, and they showed a very low explanatory power. Several studies have indicated that different thermal descriptors may be relevant not only for the community structure but also for macroinvertebrate distribution, occurrence and presence: accumulated degree days have a direct bearing on growth rate (Watanabe et al., 1999; Knispel et al., 2006), maximum temperature modifies the composition of mayflies species (Gustafson, 2008) and annual temperature range is related to seasonal variability (Eady et al., 2013).

In this study, we found that the monthly range was relevant for the 
seasonal variability of macroinvertebrates, contrary to the study by Haidekker and Hering (2008). This may be due to the fact that these authors found a fluctuation range in their rivers between 2.6 and $7.9^{\circ} \mathrm{C}$, which is narrower than high fluctuation found in our measurements (Quepuca $3.79-13.55^{\circ} \mathrm{C}$ and Pangue $4.55-11.56^{\circ} \mathrm{C}$ ) and others studies in rivers of Idaho, USA $\left(2.5-13^{\circ} \mathrm{C}\right)$ (Gustafson, 2008).

The redundancy analysis (RDA) determined that the first two axes explained $35.2 \%$ of variance and were highly correlated with the mean monthly temperature. Likewise, the first two axes of the PCA explained $69.8 \%$ of the variation in macroinvertebrate assemblage, suggesting that a proportion of macroinvertebrate variability could be explained by thermal descriptors, which is consistent with the results obtained by Gustafson (2008) and Haidekker and Hering (2008). From the RDA model, it was also possible to observe that the abundances of the macroinvertebrates families presented positive and negative correlations with the temperature, which was also verified by the weighted average regression models.

The families Gripoterygidae and Austroperlidae reaching optimal values and greater abundance at low water temperature $\left(3.96-6.94{ }^{\circ} \mathrm{C}\right)$, in contrast to Notonemouridae and Perlidae, which had registered optimal values and higher abundances at warmer temperatures $\left(9.11-13.88^{\circ} \mathrm{C}\right)$. This different thermal behavior by the group Plecoptera could be attributed to the metabolic requirements or lifehistory adaptations (Haidekker and Hering, 2008; Stark et al., 2009). The families Hydropsychidae, Hidroptilidae and Hidrobiosidae (Trichoptera) presented a positive correlation with temperature reaching optimal values at warmer temperatures $\left(>8.8^{\circ} \mathrm{C}\right)$ and their higher abundances were recorded at a mean temperature higher than $12^{\circ} \mathrm{C}$. Springer (2010) and Roux et al. (1992) found that such families are able to inhabit and tolerate high temperatures, given that their metabolism works best at temperatures between $5-20^{\circ} \mathrm{C}$. In contrast, optimal values of Helicophidae were found at a lower water temperature $\left(5-7.2^{\circ} \mathrm{C}\right)$, however their thermal tolerance is still little known, because it is a family rarely collected (Källsen and Johanson, 2010). Others as Hydrobiidae (Gastropoda) and Elmidae (Coleoptera) are families that tolerates wide temperature ranges (Quinn et al., 1994; Elliott, 2008), but this study showed that Hydrobiidae was restricted to low water temperature with a narrow tolerance to this variable, while Elmidae showed the opposite pattern.

In addition to the influence of water temperature, other variables were also important to explain the community of benthic macroinvertebrates. Among those, the current velocity was the best predictor of community composition ( $\mathrm{pRDA}=17.7 \%$ ), with a negative correlation with river width, conductivity, average temperature and monthly range. The observed correlation confirms the relevance of hydrological parameters on community metrics, since they directly affects water quality, food sources, substrate composition, oxygen content and habitat diversity (Quinn and Hickey, 1990; Sandin, 2003).

The present study is one of the first in South America (Chile) to use the maximum tolerances of benthic macroinvertebrates to predict the future effects of global warming on aquatic communities and revealed that global warming could alter the community composition of macroinvertebrates, especially families with a low tolerance to water temperature increase. The results obtained by CONAMA (2006) suggest that the surface air temperature would increase considerably in the future, particularly in the Andes region $\left(>5^{\circ} \mathrm{C}\right)$. This condition could increase gradually the water temperature of the Lomín, Quepuca y Pangue streams, due to the high relationship for air and water temperature variables $(r \geq 0.90)$ (Caissie, 2006; Pedreros et al., 2013). These changes in the water temperature could lead to displacement in altitude and latitude of some macroinvertebrates families for the year 2070.

Therefore, we could assume that the presence of families with broader thermal tolerance could survive and increase their distribution range in the new climatic scenarios, while families with narrower thermal tolerance and limited ecological plasticity could reduce their distribution range. In order to resist the new habitat conditions, benthic macroinvertebrates could use some survival strategies which includes egg diapause (Vinogradova, 2007), drift movement (Merritt and Cummins, 1996) or flight behavior in adult stages (May, 2019). However, it is difficult to know if the change in the distribution range will be linear or the species could gradually adapt to global warming (Isaak et al., 2016), since the speed of warming in a community's habitat and the speed with which aquatic communities could change their ranges is largely unknown to the study area.

The families of the group Plecoptera were the most vulnerable in all the sampling sites, because they are adapted to live at low-temperature and high current velocity (Stark et al., 2009). This is consistent with the results obtained by Palma and Figueroa (2008); Fochetti and Tierno de Figueroa (2008); Tierno de Figueroa et al. (2010) and Li et al. (2013) who also confirm the vulnerability of this group to global warming. As temperature regimes are changing substantially, major changes are expected in the presence and distribution of the species. Our results emphasize a decrease in biodiversity in the assessed Andean area due to the loss or displacement of cold-water families, increasing the risk of extinction of some families (e.g., Plecoptera). While the intermediate or warm-water families will be probably more stable or will increase in abundance and richness between 2070 and 2100, suggesting positive effects of global warming for warm-water families. These predictions were consistent with a number of long-term studies conducted in Australia (Chessman, 2009; Nichols et al., 2010), United States (Poff et al., 2010), Europe (Durance and Ormerod, 2009) and Asia (Li et al., 2013).

In conclusion, macroinvertebrate families tolerance change with the temperature pattern studied and could be used as indicators of future climate change in Andean streams in the Southern Hemisphere. It is important to highlight that freshwater biota of the study area is largely endemic (28.6\% Ephemeroptera, 10.4\% Plecoptera and $70.6 \%$ Trichoptera; Figueroa et al., 2013) and possesses a typically Gondwanian geographical distribution (Valdovinos, 2008). Hence, our approaches could be replicated to other climatic and geographical areas of South America, with the objective of building models that allow estimating the effect of temperature on macroinvertebrate species.

\section{CRediT authorship contribution statement}

Pablo Pedreros: Conceptualization, Methodology, Investigation, Formal analysis, Writing - original draft. Meyer Guevara-Mora: Methodology, Software, Formal analysis, Writing - review \& editing. Alejandra Stehr: Writing - review \& editing. Alberto Araneda: Methodology, Writing - review \& editing. Roberto Urrutia: Writing review \& editing, Funding acquisition.

\section{Declaration of Competing Interest}

The authors declare that they have no known competing financial interests or personal relationships that could have appeared to influence the work reported in this paper.

\section{Acknowledgments}

This research was supported by Fondecyt Postdoctoral $\mathrm{N}^{\circ} 3180356$ and ANID/FONDAP/15130015 Projects. We thank César Pedreros, Catalina Verdugo, María Elisa Díaz, Mariel Bonilla and José Cáceres for helping with the fieldwork; Patricia Jana and Denisse Álvarez for the help in the figures; and to Symbols courtesy of the Integration and Application Network (ian.umces.edu/symbols/). Finally, we would like to thank the anonymous reviewers for their thoughtful comments and suggestions.

\section{References}

Anderson, M.J., Ellingsen, K.E., McArdle, B.H., 2006. Multivariate dispersion as a 
measure of beta diversity. Ecol. Lett. 9, 683-693. https://doi.org/10.1111/j.14610248.2006.00926.x.

Angilletta, M.J., Niewiarowski, P.H., Navas, C.A., 2002. The evolution of thermal physiology in ectotherms. J. Therm. Biol. 27, 249-268. https://doi.org/10.1016/S0306 4565(01)00094-8.

Bêche, L.A., Resh, V.H., 2007a. Biological traits of benthic macroinvertebrates in California mediterranean-climate streams: long-term annual variability and trait diversity patterns. Fund. App. Limnol. 169, 1-23. https://doi.org/10.1127/1863-9135/ 2007/0169-0001.

Bêche, L.A., Resh, V.H., 2007b. Short-term climatic trends affect the temporal variability of macroinvertebrates in California 'mediterranean' streams. Freshw. Rev. 52, 2317-2339. https://doi.org/10.1111/j.1365-2427.2007.01859.x.

Birks, H.J.B., Line, J.M., Juggins, S., Stevenson, A.C., Ter Braak, C.J.F., 1990. Diatoms and pH reconstruction. Philos. Trans. Biol. Sci. 327, 263-278. https://doi.org/10.1098/ rstb.1990.0062.

Borcard, D., Gillet, F., Legendre, P., 2011. Numerical Ecology With R. Springer-Verlag, New York, USA.

Brittain, J., 1991. Effect of temperature on egg development in the Australian stonefly genus, Austrocercella Illies (Plecoptera : Notonemouridae). Aust. J. Mar. Fresh. Res. 42, 107-114.

Brittain, J.E., Castella, E., Knispel, S., Lencioni, V., Lods-Crozet, B., Maiolini, B., Milner, A.M., Slatveit, S.J., Snook, D.L., 2003. Ephemeropteran and plecopteran communities in glacial rivers. In: Gaino, E. (Ed.), Research Update on Ephemeroptera and Plecoptera. University of Perugia, Perugia, Italy, pp. 271-277.

Caissie, D., 2006. The thermal regime of rivers: a review. Freshw. Rev. 51, 1389-1406. https://doi.org/10.1111/j.1365-2427.2006.01597.x.

Carrasco, J.F., Casassa, G., Quintana, J., 2005. Changes of the $0^{\circ} \mathrm{C}$ isotherm and the equilibrium line altitude in central Chile during the last quarter of the 20th century. Hydrol. Sci. J. Des Sci. Hydrol. 50, 933-948. https://doi.org/10.1623/hysj.2005.50. 6.933.

Chessman, B.C., 2009. Climatic changes and 13-year trends in stream macroinvertebrate assemblages in New South Wales, Australia. Glob. Change Biol. 15, 2791-2802. https://doi.org/10.1111/j.1365-2486.2008.01840.x.

Chessman, B.C., 2012. Biological traits predict shifts in geographical ranges of freshwater invertebrates during climatic warming and drying. J. Biogeogr. 39, 957-969. https:// doi.org/10.1111/j.1365-2699.2011.02647.x.

CONAMA, 2006. Estudio de la variabilidad climática en Chile para el siglo XXI, Departamento de Geofísica, Facultad de Ciencias Físicas y Matemáticas. Universidad de Chile, Santiago, Chile.

Dallas, H.F., Rivers-Moore, N.A., 2012. Critical Thermal Maxima of aquatic macroinvertebrates: towards identifying bioindicators of thermal alteration. Hydrobiologia 679, 61-76. https://doi.org/10.1007/s10750-011-0856-4.

Dallas, H., Ross-Gillespie, V., 2015. Sublethal effects of temperature on freshwater organisms, with special reference to aquatic insects. Water Sa 41, 712-726. https://doi. org/10.4314/WSA.V41I5.15.

Dallman, P.R., 1998. Plant Life in the World's Mediterranean Climates. University of California Press, Los Angeles.

Domínguez, E., Fernandez, H., 2009. Macroinvertebrados bentónicos sudamericanos: Sistemática y biología, Tucumán, Argentina.

Domínguez, E., Molineri, C., Pescador, M., Hubbard, M.D., Nieto, C., 2006. Ephemeroptera of South America. Pensoft, Sofía, Bulgaria.

Domisch, S., Araújo, M.B., Bonada, N., Pauls, S.U., Jähnig, S.C., Haase, P., 2013 Modelling distribution in European stream macroinvertebrates under future climates. Glob. Change Biol. 19, 752-762. https://doi.org/10.1111/gcb.12107.

Durance, I., Ormerod, S.J., 2007. Climate change effects on upland stream macroinvertebrates over a 25-year period. Glob. Change Biol. 13, 942-957. https://doi.org/ 10.1111/j.1365-2486.2007.01340.x.

Durance, I., Ormerod, S.J., 2009. Trends in water quality and discharge confound longterm warming effects on river macroinvertebrates. Freshw. Rev. 54, 388-405. https://doi.org/10.1111/j.1365-2427.2008.02112.x.

Eady, B.R., Rivers-Moore, N.A., Hill, T.R., 2013. Relationship between water temperature predictability and aquatic macroinvertebrate assemblages in two South African streams. Afr. J. Aquat. Sci. 38, 163-174. https://doi.org/10.2989/16085914.2012. 763110 .

Elliott, J.M., 2008. The ecology of riffle beetles (Coleoptera: Elmidae). Freshw. Rev. 1, 189-203. https://doi.org/10.1608/FRJ-1.2.4.

Eriksen, C.H., 1964. Evidence of a spring rise in metabolic rate in the burrowing mayfly Ephemera simulans Walker. Hydrobiologia 23, 506-510. https://doi.org/10.1007/ BF00179498.

Falvey, M., Garreaud, R.D., 2009. Regional cooling in a warming world: recent temperature trends in the southeast Pacific and along the west coast of subtropical South America (1979-2006). J. Geophys. Research 114, D04102. https://doi.org/10.1029/ 2008JD010519.

Figueroa, R., Bonada, N., Guevara, M., Pedreros, P., Correa-Araneda, F., Díaz, M., Ruiz V., 2013. Freshwater biodiversity and conservation in mediterranean climate streams of Chile. Hydrobiologia 719, 269-289. https://doi.org/10.1007/s10750-013-1685-4.

Filipe, A.F., Lawrence, J.E., Bonada, N., 2013. Vulnerability of stream biota to climate change in mediterranean climate regions: a synthesis of ecological responses and conservation challenges. Hydrobiologia 719, 331-351. https://doi.org/10.1007/ s10750-012-1244-4.

Fochetti, R., Tierno de Figueroa, J.M., 2008. Global diversity of stoneflies (Plecoptera; Insecta) in freshwater. Hydrobiologia 595, 365-377. https://doi.org/10.1007/ s10750-007-9031-3.

Gajardo, R., 1994. La vegetación natural de Chile: clasificación y distribución geográfica, Santiago, Chile.

Gustafson, M.P., 2008. Effects of thermal regime on mayfly assemblages in mountain streams. Hydrobiologia 605, 235-246. https://doi.org/10.1007/s10750-008-9357-5.

Habit, E., Piedra, P., Ruzzante, D.E., Walde, S.J., Belk, M.C., Cussac, V.E., Gonzalez, J. Colin, N., 2010. Changes in the distribution of native fishes in response to introduced species and other anthropogenic effects. Global Ecol. Biogeogr. 19, 697-710. https:// doi.org/10.1111/j.1466-8238.2010.00541.x.

Haidekker, A., Hering, D., 2008. Relationship between benthic insects (Ephemeroptera, Plecoptera, Coleoptera, Trichoptera) and temperature in small and medium-sized streams in Germany: a multivariate study. Aquatic Ecol. 42, 463-481. https://doi. org/10.1007/s10452-007-9097-z.

Hajek, E., 1991. In: Hajek, E. (Ed.), Medio Ambiente en Chile. La situación ambiental en América Latina, Buenos Aires, pp. 237-294.

Hawkins, C.P., Hogue, J.N., Decker, L.M., Feminella, J.W., 1997. Channel morphology, water temperature, and assemblage structure of stream insects. J. N. Am. Benthol Soc. 16, 728-749. https://doi.org/10.2307/1468167.

Heino, J., Virkkala, R., Toivonen, H., 2009. Climate change and freshwater biodiversity: detected patterns, future trends and adaptations in northern regions. Biol. Rev. 84, 39-54. https://doi.org/10.1111/j.1469-185X.2008.00060.x.

Hering, D., Moog, O., Sandin, L., Verdonschot, P.F.M., 2004. Overview and application of the AQEM assessment system. Hydrobiologia 516, 1-20. https://doi.org/10.1023/ B:HYDR.0000025255.70009.a5.

Hering, D., Schmidt-Kloiber, A., Murphy, J., Lücke, S., Zamora-Muñoz, C., LópezRodríguez, M.J., Huber, T., Graf, W., 2009. Potential impact of climate change on aquatic insects: a sensitivity analysis for European caddisflies (Trichoptera) based on distribution patterns and ecological preferences. Aquat. Sci. 71, 3-14. https://doi. org/10.1007/s00027-009-9159-5.

IPCC, 2013. Summary for Policymakers. Cambridge University Press, Cambridge, UK, and New York, USA.

Isaak, D.J., Wollrab, S., Horan, D., Chandler, G., 2012. Climate change effects on stream and river temperatures across the northwest U.S. From 1980-2009 and implications for salmonid fishes. Clim. Change 113, 499-524. https://doi.org/10.1007/s10584011-0326-z.

Isaak, D., Young, M., Luce, Ch, Hostetler, S., Wenger, S., Peterson, E., Ver Hoef, J., Groce, M., Horan, D., Nagel, D., 2016. Slow climate velocities of mountain streams portend their role as refugia for cold-water biodiversity. PNAS 113 (16), 4374-4379. https:// doi.org/10.1073/pnas.1522429113.

Källsen, M., Johanson, K.A., 2010. Description of Helicopha queenslandensis sp. nov. from Australia (Trichoptera: Helicophidae). Aquat. Insects 32, 25-28. https://doi.org/10. 1080/01650420903113745.

Kaushal, S.S., Likens, G.E., Jaworski, N.A., Pace, M.L., Sides, A.M., Seekell, D., Belt, K.T., Secor, D.H., Wingate, R.L., 2010. Rising stream and river temperatures in the United States. Front. Ecol. Environ. 8, 461-466. https://doi.org/10.1890/090037.

Kishi, D., Murakami, M., Nakano, S., Maekawa, K., 2005. Water temperature determines strength of top-down control in a stream food web. Freshw. Rev. 50, 1315-1322. https://doi.org/10.1111/j.1365-2427.2005.01404.x.

Knispel, S., Sartori, M., Brittain, J.E., 2006. Egg development in the mayflies of a Swiss glacial floodplain. J. N. Am. Benthol. Soc. 25, 430-443. https://doi.org/10.1899/ 0887-3593(2006)25[430:EDITMO]2.0.CO;2.

Köppen, W., 1923. Die Klimate der Erde, Berlin, Alemania.

Lêps, J., Ŝmilauer, P., 2003. Multivariate Analysis of Ecological Data Using CANOCO. Cambridge University Press, Cambridge.

Li, F., Cai, Q., Jiang, W., Qu, X., 2012. The response of benthic macroinvertebrate communities to climate change: evidence from subtropical mountain streams in Central China. Int. Rev. Hydrobiol. 97, 200-214. https://doi.org/10.1002/iroh.201111489.

Li, F., Chung, N., Bae, M.-J., Kwon, Y.-S., Kwon, T.-S., Park, Y.S., 2013. Temperature change and macroinvertebrate biodiversity: assessments of organism vulnerability and potential distributions. Clim. Change 119, 421-434. https://doi.org/10.1007/ s10584-013-0720-9.

Mantyka-Pringle, C.S., Martin, T.G., Moffatt, D.B., Linke, S., Rhodes, J.R., 2014 Understanding and predicting the combined effects of climate change and land-use change on freshwater macroinvertebrates and fish. J. Appl. Ecol. 51, 572-581. https://doi.org/10.1111/1365-2664.12236.

May, M.L., 2019. Dispersal by aquatic insects. In: Del-Claro, K., Guillermo, R. (Eds.), Aquatic Insects. Springer, Cham, pp. 35-73.

McKie, B.G., Cranston, P.S., Pearson, R.G., 2004. Gondwanan mesotherms and cosmopolitan eurytherms: effects of temperature on the development and survival of Australian Chironomidae (Diptera) from tropical and temperate populations. Mar. Freshwater Res. 55, 759-768. https://doi.org/10.1071/MF04023.

Merritt, R.W., Cummins, K.W., 1996. An Introduction to the Aquatic Insects of North America. Kendall Hunt, Dubuque, Iowa.

Morrill, J.C., Bales, R.C., ASCE, M., Conklin, M.H., 2005. Estimating stream temperature from air temperature: implications for future water quality. J. Environ. Eng. 131, 139-146. https://doi.org/10.1061/(ASCE)0733-9372(2005)131:1(139).

Myers, N., Mittermeier, R.A., Mittermeier, C.G., da Fonseca, G.A.B., Kent, J., 2000. Biodiversity hotspots for conservation priorities. Nature 403, 853-858. https://doi. org $/ 10.1038 / 35002501$.

Nichols, S.J., Robinson, W.A., Norris, R.H., 2010. Using the reference condition maintain the integrity of a bioassessment program in a changing climate. J. N. Am. Benthol. Soc. 29, 1459-1471. https://doi.org/10.1899/09-165.1.

Oksanen, J., Blanchet, F.G., Friendly, M., Kindt, R., Legendre, P., McGlinn, D., Minchin, P.R., O’Hara, R.B., Simpson, G.L., Solymos, P., Stevens, M.H.H., Szoecs, E., Wagner, H., 2016. Vegan: Community Ecology Package. R package version 2, pp. 3-5.

Palma, A., Figueroa, R., 2008. Latitudinal diversity of Plecoptera (Insecta) on local and global scales. Illesia 4, 81-90.

Parmesan, C., Yohe, G., 2003. A globally coherent fingerprint of climate change impacts across natural systems. Nature 421, 37-42. https://doi.org/10.1038/nature01286.

Pedreros, P., Guevara, M., Figueroa, R., Araneda, A., Stehr, A., Link, O., Urrutia, R., 2013. 
Comportamiento térmico en ríos mediterráneos andinos de la zona centro-sur de Chile. Limnetica 32, 87-96. https://doi.org/10.23818/limn.32.09.

Poff, N.L., Pyne, M.I., Bledsoe, B.P., Cuhaciyan, C.C., Carlisle, D.M., 2010. Developing linkages between species traits and multiscaled environmental variation to explore vulnerability of stream benthic communities to climate change. J. N. Am. Benthol. Soc. 29, 1441-1458. https://doi.org/10.1899/10-030.1.

Quinn, J.M., Hickey, C.W., 1990. Characterisation and classification of benthic macroinvertebrate communities in $88 \mathrm{New}$ Zealand rivers in relation to environmental factors. N. Z. J. Mar. Freshwater Res. 24, 387-409. https://doi.org/10.1080/ 00288330.1990 .9516432$.

Quinn, J.M., Steele, G.L., Hickey, C.W., Vickers, M.L., 1994. Upper thermal tolerances of twelve New Zealand stream invertebrate species. N. Z. J. Mar. Freshwater Res. 28, 391-397. https://doi.org/10.1080/00288330.1994.9516629.

Rosenzweig, C., Karoly, D., Vicarelli, M., Neofotis, P., Wu, Q., Casassa, G., Menzel, A., Root, T.L., Estrella, N., Seguin, B., Tryjanowski, P., Liu, C., Rawlins, S., Imeson, A., 2008. Attributing physical and biological impacts to anthropogenic climate change. Nature 453, 353-357. https://doi.org/10.1038/nature06937.

Roux, C., Tachet, H., Bournaud, M., Cellot, B., 1992. Stream continuum and metabolic rate in the larvae of five species of Hydropsyche (Trichoptera). Ecography 15, 70-76. https://doi.org/10.1111/j.1600-0587.1992.tb00010.x.

Sandin, L., 2003. Benthic macroinvertebrate in Swedish streams: community structure, taxon richness, and environmental relations. Ecography 26, 269-282. https://doi. $\operatorname{org} / 10.1034 / j .1600-0587.2003 .03380 . x$.

Springer, M., 2010. Capítulo 7: Trichoptera. Rev. Biol. Trop. 58, 151-198.

Stark, B.P., Froehlich, C., Zuñiga, M., 2009. South American Stoneflies (Plecoptera). Pensoft, Sofia-Moscow.
Sweeney, B.W., 1993. Effects of streamside vegetation on macroinvertebrate communities of White Clay Creek in eastern North America. P. Acad. Nat. Sci. Phila. 291-340.

Ter Braak, C.F.J., Looman, C.W.N., 1986. Weighted averaging, logistic regression and the Gaussian response model. Vegetatio 65, 3-11. https://doi.org/10.1007/BF00032121. Tierno de Figueroa, J.M., López-Rodríguez, M.J., Lorenz, A., Graf, W., Schmidt-Kloiber, A., Hering, D., 2010. Vulnerable taxa of European Plecoptera (Insecta) in the context of climate change. Biodivers. Conserv. 19, 1269-1277. https://doi.org/10.1007/ s10531-009-9753-9.

Valdovinos, C., 2008. Invertebrados dulceacuícolas. In: Libros, O. (Ed.), Biodiversidad De Chile: Patrimonio Y Desafíos. CONAMA, Santiago, Chile, pp. 202-222.

Van Vliet, M.T.H., Ludwig, F., Zwolsman, J.J.G., Weedon, G.P., Kabat, P., 2011. Global river temperatures and sensitivity to atmospheric warming and changes in river flow. Water Resour. Res. 47, W02544. https://doi.org/10.1029/2010WR009198.

Vannote, R.L., Sweeney, B.W., 1980. Geographic analysis of thermal equilibria: a conceptual model for evaluating the effect of natural and modified thermal regimes on aquatic insect communities. Am. Nat. 115, 667-695.

Vinogradova, E.B., 2007. Diapause in aquatic insects, with emphasis on mosquitoes. In: Alekseev, V.R., de Stasio, B.T., Gilbert, J.J. (Eds.), Diapause in Aquatic Invertebrates Theory and Human Use. Springer, Dordrecht, pp. 83-113.

Ward, J.V., Stanford, J.A., 1982. Thermal responses in the evolutionary ecology of aquatic insects. Ann. Review Entomol. 27, 97-117. https://doi.org/10.1146/ annurev.en.27.010182.000525.

Watanabe, N.C., Mori, I., Yoshitaka, I., 1999. Effect of water temperature on the mass emergence of the mayfly Ephoron shigae in a Japanese river (Ephemeroptera: Polymitarcyidae). Freshw. Rev. 41, 537-541. https://doi.org/10.1046/j.1365-2427. 1999.00398.x. 